\title{
Teachers' Experiences with Networked Classrooms in Norway
}

\author{
Ingrid Helleve ${ }^{1}$ and Aslaug Grov Almås ${ }^{2}$ \\ ${ }^{1}$ University of Bergen, P.O. Box 7800, 5020 Bergen, Norway \\ ${ }^{2}$ Western Norway University of Applied Sciences, Postbox 7030, 5020 Bergen, Norway \\ Correspondence should be addressed to Ingrid Helleve; ingrid.helleve@uib.no
}

Received 6 March 2017; Accepted 28 May 2017; Published 4 July 2017

Academic Editor: Auli Toom

Copyright (C) 2017 Ingrid Helleve and Aslaug Grov Almås. This is an open access article distributed under the Creative Commons Attribution License, which permits unrestricted use, distribution, and reproduction in any medium, provided the original work is properly cited.

\begin{abstract}
The aim of this study, based on response on a questionnaire from 65 teachers in upper secondary schools, is to gain insight into how teachers experience and practice their role as leaders in the digital classroom. Research shows that teachers seldom are asked about their opinions concerning use of technical device. From 2007 all Norwegian students in upper secondary schools were given a computer from the authorities. Politicians argued for pedagogical use of ICT, for example, through interactive device like social networking sites. However, recent national reports show that teachers mainly use ICT for administrative and not for pedagogical purposes. Findings from the current study show that teachers adjust the technology to their existing pedagogy and continue their existing practice. To a small extent the technology's interactive abilities are utilized. Technological device is powerful. Possible consequences of placing technology on every student's desk are discussed. The teachers' future concern is to control Internet and to have possibilities to develop and discuss pedagogical use of technology in classrooms with their colleagues.
\end{abstract}

\section{Introduction}

Since 2007 all Norwegian pupils in upper secondary school were given a computer from political authorities [1]. Schools were equipped with technological facilities. Erstad [2] argues that what he called "the driving forces" of school development pushed in the direction of more student active learning activities where the teacher acts as a supervisor and pupils take responsibility for producing and sharing knowledge supported by technological device. By the introduction of computers into the classrooms teachers had to handle the pedagogical challenge of how to utilize technology for pedagogical purposes and simultaneously act as leaders of networked classrooms. The Norwegian political program for digital competence [3] maintained that, within 2008, Norway should be ranked on top when it comes to digital equipment in schools. The National Curriculum plan in 2006 [4] proved that digital competence should be one of five basic competences in line with reading, oral expression, writing, and mathematics. Another political document, Whitepaper 44, argues for social networking sites (SNS) as a support for learning [5]. According to the Whitepaper schools' SNS usage relates to pupils' confidence in digital media, development of identity, and social competence. Since youths are highly engaged with SNS in everyday life, it is argued that SNS are well suited for pedagogical purposes. Since more than 90 percent of pupils in upper secondary schools use SNS, these sites pedagogical purposes may strengthen the relevance of education. However, recent results through a national report called Monitor ([6]: 75) show that to a large extent Norwegian teachers use technology for administrative, and not for pedagogical, purposes. The reports on conditions concerning use of ICT in schools are published regularly. Compared to the previous report published three years ago [7] the researchers can tell that there is no change. Teachers use ICT mainly for administrative and not for pedagogical purposes. Further, the report claims that teachers play an important role in influencing pupils' digital competence and conclude that teachers need to learn more. They need more skills and courses enhancing competence. What the teachers say, on the other hand, is that what has influenced their digital competence most is what they have learned from unsystematic activities like trying and failing. The report concludes that it is strange that teachers claim to learn more 
from peer learning and informal and unorganized activities. The conclusion of the report is that what the teachers say may be correct, but that the answers make it difficult for the authorities to make plans. For leaders it is complicated to rule through trying and failing, self-studies, and peer learning. Research shows that teachers themselves seldom are asked about their opinions concerning use of technical device in classrooms [8, 9]. Underwood and Dillon [10] claim that classrooms are changed when the technology is introduced, but the changes are not necessarily those that are wanted. Studies show that what teachers believe in seems to be important $[9,11-13]$. Since beliefs or lack of beliefs seems to be the key-factor for understanding how technology is used in schools, it may be crucial to hear teachers' opinions in order to understand more of the implementation process $[8,14]$. The aim of the study is to gain more insight into how teachers experience and practice their role as leaders of the digital classroom.

The research questions are as follows:

(1) How does a selection of teachers in Norwegian upper secondary schools use technology in their classrooms?

(2) What needs and expectations do the teachers have concerning technology?

1.1. Technology in Education. The aura surrounding technology seems to be automatically accepted by policymakers as advancement. Politicians and educational authorities throughout the world are trying to integrate technology into their educational systems hoping that technology will improve education [15]. Instrumental rationality makes us think that technology can solve all kinds of challenges [16, 17]. Rodríguez et al. [18] argue that attempts to improve education with modern machines date from early twentieth century $[19,20]$. What happens according to Callister and Dunne [21] is that inventions come and go, while the classrooms look the same, and teachers' teaching and learning practice continues. Cuban and Tyack [22] assert, however, that computers are the most powerful teaching and learning machines. Students and teachers can interact with computers in ways that are impossible with other media such as film or television. Papert [23] went as far as to say that in the future there would be no more schools because the computer would change it all. Following the same argumentation Säljö [24] says that the computer can be the most serious challenge to the traditional classroom as we have known it for thousands of years ([24]: 46). ICT has a powerful defining impact on all patterns and modes of our lives and hence is bound to lead to dramatic changes in education as well [10]. According to McFarlane [25] there has been a confusion of purposes concerning use of educational technology at the heart of policies in England. McFarlane mentions three partly contrary areas. First, ICT is defined as a set of skills or competences, secondly as a vehicle for teaching and learning, and finally as an agent for transformative change. The idea of ICT in education was not asked for by teachers. The origins are outside the educational system $[18,26]$. Research shows that during implementation greater emphasis was placed on technology than on pedagogy
$[2,27]$. European Schoolnet [28] pointed out that teachers use ICT to support their existing pedagogies and that technology is used most when it fits with traditional practices. Teachers use computers because their conceptions of how to use ICT already fit within their existing notions of effective teaching practices. The greatest impact of the technology is with teachers who are experienced users and who have already made progress integrating ICT into their teaching. Teachers who perceive a highly positive impact of ICT use it in the most project-oriented, collaborative, and experimental ways. The same findings are pointed out in Becta and "The ICT Test Bed Evaluation," where Somekh et al. [29] provide evidence that teachers use ICT to support existing pedagogies: "New technologies that provide a good 'fit' with existing practices, such as interactive whiteboards, are the first to be embedded" ([29]: 7). Teachers are blamed for resistance to change. Pajares [30] used the term teachers' beliefs and asserted that research has not put enough emphasis on the fact that it is teachers' attitudes and values, which means what teachers believe in, that is guiding their pedagogical practice. Another concept that may be fruitful in order to understand teachers' resistance and the reason why political visions may be difficult to transform into practice in classrooms is teachers' agency. The interpretation of agency is based on an understanding that people do not merely react and repeat a given practice. Oppositely, people react autonomously and transform their world in order to take control. Thus, agency can be understood as the capacity to initiate purposeful action that implies will, autonomy, freedom, and choice [31].

Applied to teachers' professional practice agency denotes the ability to act on their own and step out of regulations. For teachers agency may as well mean support to political decisions as active restraint [32].

1.2. Control and Leadership. In spite of the strong wish from educational authorities in the direction of student active learning activities, classrooms are often equally furnished. Pupils have their individual desks turned against the teacher's desk and the teacher communicates with one pupil at the time [33]. Research on classroom communication patterns seems to agree to the fact that time is spent on what is referred to as IRF or IRE sequences $[34,35]$. The letter (I) represents an initiative from the teacher, often a question concerning already known information. To the teacher's initiative pupils are supposed to respond $(\mathrm{R})$ followed by feedback $(\mathrm{F})$ or evaluation (E) from the teacher. For pupils to know the rules of how to succeed is related not only to the correct answer, but also to knowledge of how to practice the correct rules for conduct. Mehan's conclusion is that teachers often ask questions concerning information that is already known. To be competent as a pupil means to respond to the teacher's invitation and to understand how to behave and answer. Later Cazden's [36] findings correspond to Edwards and Mercer's [37]. They claim that teachers do not primarily ask questions in order to come up with new knowledge. The main aim for the teacher is to keep control. According to Wertsch [38] this is the discourse pattern that has turned out to be most resistant against change across classrooms. But is it necessarily wrong to keep control? Teachers are leaders and 
TABLE 1: Years of experience as teachers.

\begin{tabular}{lc}
\hline $0-4$ years & $20.0 \%$ \\
$5-14$ years & $30.7 \%$ \\
More than 14 years & $47.7 \%$ \\
Not answered & $1.3 \%$ \\
\hline
\end{tabular}

TABLE 2: PC in classrooms.

\begin{tabular}{lc}
\hline \multicolumn{2}{l}{ How many years have you had the computer as part of classroom } \\
furniture?
\end{tabular}

all leaders need to have a certain degree of control $[39,40]$. When pupils are working in groups it is more difficult for the teacher to keep control and when communication is moved out of the physical room and into the space, teachers must find other ways to keep control and overview. Anxiety for losing control is maybe the main reason for maintaining what is called the IRE pattern [41].

Computers have interactive abilities making them suitable as a space for collaboration [42]. It has the possibility for building new spaces inside the physical space like, for example, SNS. Due to its abilities for storing, visualizing, and availability the technology offers possibilities for sharing and developing new knowledge [43]. The computer imposed on traditional forms of teaching cannot improve the quality or productivity of teaching [44]. On the contrary Kompf [45] argues that the technology's self-organizing capacity may lead to control over education passing out of the hands of educators into the hands of administrators.

\section{Methods}

2.1. Procedure. Data from teachers in 20 upper secondary schools was collected through questionnaires during spring term 2013. The schools were approached through gatekeepers (i.e., student teachers from the University). Teachers at these schools were invited to a web address with access to the web-survey. The web-based questionnaires were distributed and filled out with the Learning Platform (LMS) Its Learning. The study has been approved by the Norwegian Social Science Data Services (NSD).

2.2. Sample. 65 teachers participated in the study. The mean age of the sample is 46.1. 41.5 percent of the sample are female. Table 1 shows how long experience the teachers had.

Table 2 illustrates how many years technology had been part of the classroom furniture.

2.3. Data Collection Instruments. The instrument was an open-ended questionnaire which first asked for the abovementioned demographic data. The questionnaire is developed based on a previous questionnaire meant for pupils in upper secondary schools. The results from this study showed among other results that pupils spend a lot time on Facebook during lessons in schools [46]. The aim of the current study is to get teachers' opinions on some of the same questions. The questionnaires are developed in collaboration with partners at the Norwegian Policy University College, Stord Haugesund University College, and Monash University in Australia. The current study is part of the international research project Ethics, Social Media and Teacher Education.

The questionnaire asked for eventual rules for use of computers and Internet in the classroom and if the introduction of computers had caused any differences in the organization of the classrooms in handling of cheating. Further the teachers were asked about their opinions about social media (SNS), and how they eventually used these media for educational purposes. Finally they were asked what they regarded as the most urgent challenges concerning present and future use of computers in classrooms.

2.4. Data Analysis. We did not use a priori system of codes and categories for the analysis besides those which were related to the questions asked. The authors first interpreted the qualitative statements individually. Next, each of the authors categorized the statements using a grounded theory approach. The authors compared and discussed the categories. There was a high level of reciprocal understanding. With minor adjustments, the authors arrived at the categories for the open-ended questions as presented in the findings.

\section{Findings}

The findings answer the research questions: first, how the technology is used in the classrooms, second, the teachers' needs and expectations concerning use of technology.

Results show that all the teachers $(n=65)$ report that their pupils are continuing being connected to Internet during the school-day. 79.1 percent say that they would like to decide themselves when Internet should be turned on and off.

Table 3 shows for what purpose the teachers use the technology in their classrooms. Films, for example, from YouTube are often mentioned in the open questionnaire as a good way of having the pupils' collective attention, often as an introduction to a lesson. PowerPoint is also a way of gaining control by preparing the presentation before the lesson starts. The possibilities for using web-based learning resources within different subjects are spoken about in the open questionnaire $(n=19)$. Such resources are updated and are good alternatives to books that become old-fashioned and outdated. It is also important for the teachers that pupils easily can search and find information $(n=10)$. Writing with computers is easier than pen and pencil $(n=7)$. Technology offers possibilities for structure and order, that is, LMS ( $n=$ 7). Some teachers assert that pupils become more creative when they use technology $(n=3)$. Digital competence is said to be important $(n=3)$. Only one teacher mentions the possibilities for contact with other people outside the classroom or even outside the country.

When it comes to digital tests as shown in Table 4 and the question of cheating, 55.4 percent of the teachers use 
TABLE 3: Purpose of technology.

\begin{tabular}{|c|c|c|c|c|c|c|c|}
\hline \multicolumn{8}{|c|}{ How do you use the technology in your classroom? } \\
\hline & Not at all & $\begin{array}{c}\text { To a very } \\
\text { small extent }\end{array}$ & $\begin{array}{c}\text { To a small } \\
\text { extent }\end{array}$ & $\begin{array}{c}\text { To some } \\
\text { extent }\end{array}$ & $\begin{array}{c}\text { To a large } \\
\text { extent }\end{array}$ & $\begin{array}{c}\text { To a very } \\
\text { large extent }\end{array}$ & Not answered \\
\hline PowerPoint/Prezi & $3,7 \%$ & $9,8 \%$ & $6,1 \%$ & $31,7 \%$ & $29,3 \%$ & $12,2 \%$ & $7,3 \%$ \\
\hline Films and video & $1,2 \%$ & $6,1 \%$ & $13,4 \%$ & $41,5 \%$ & $25,6 \%$ & $4,9 \%$ & $7,3 \%$ \\
\hline Smartboard & $43,9 \%$ & $9,8 \%$ & $12,2 \%$ & $14,6 \%$ & $4,9 \%$ & $4,9 \%$ & $9,8 \%$ \\
\hline Assignments on PC & $2,4 \%$ & $4,9 \%$ & $2,4 \%$ & $19,5 \%$ & $31,7 \%$ & $31,7 \%$ & $7,3 \%$ \\
\hline OneNote & $54,9 \%$ & $12,2 \%$ & $9,8 \%$ & $9,8 \%$ & $2,4 \%$ & $2,4 \%$ & $8,5 \%$ \\
\hline
\end{tabular}

TABLE 4: Digital tests.

\begin{tabular}{ll}
\hline \multicolumn{3}{c}{ Do you use the LMS for tests? } \\
\hline Yes & $55,6 \%$ \\
No & $44,4 \%$ \\
\hline
\end{tabular}

TABLE 5: SNS for educational purposes.

\begin{tabular}{lc}
\hline \multicolumn{2}{c}{ Do you use social networking sites for educational purposes? } \\
\hline Yes & $15.4 \%$ \\
No & $75.4 \%$ \\
Not answered & $9.2 \%$ \\
\hline
\end{tabular}

digital tests. Altogether $39(n=39)$ have answered the openended question of how they handle cheating. Apparently there is a possibility for closing Internet during the tests and 20 teachers announce that they use this possibility while four $(n=4)$ use some sort of screen control. 18 teachers $(n=18)$ watch the pupils' screens from the back of the classroom. One teacher says that he talks about confidence with the pupils and that so far no cheating is revealed.

The majority of the teachers report that they are members of a social networking site (74.5\%). Table 5 shows, however, that few teachers use SNS for educational purposes. $n=11$ have answered the open questionnaire. One of them argues for his privacy as a teacher:

\section{I have decided that all kinds of communication between me and the pupils should be on estab- lished websites in order to preserve my role as a teacher and not as a friend. I do not want them inside my private sphere.}

A few teachers $(n=6)$ report that they have a Facebook group connected to the subject they teach:

\section{I have linked the LMS to Facebook in order to catch all the pupils. And then my pupils can use it the other way round; they ask questions that either I or other pupils can respond to.}

Three respondents answer that their pupils use FB for educational purposes, but as teachers they would never use it.

Table 6 shows the answers to the question of rules for how the technology should be used in the classrooms. The data
TABLE 6: Rules for use of PC in classroom.

\begin{tabular}{lcc}
\hline \multicolumn{3}{c}{ Does your class have any rules? } \\
\hline Yes & $83.1 \%$ \\
No & $9.2 \%$ \\
Do not know & $7.7 \%$ \\
\hline
\end{tabular}

TABLE 7: Organization of the classroom.

\begin{tabular}{lc}
\hline \multicolumn{2}{c}{ Has introduction of PC influenced your way of organizing the } \\
classroom? \\
\hline Yes & $52.3 \%$ \\
No & $46.2 \%$ \\
Not answered & $1.5 \%$ \\
\hline
\end{tabular}

from the open categories $(n=62)$ showed that by far the most used rule is that the screen of the computer should be closed when the lesson starts or the teacher enters the classroom $(n=52)$. Apparently, there is a conflict on how to use the technology when teachers are giving lectures:

Normally, the pupils are not allowed to use the technology when I give lectures. They should only use it when I tell them to do it. Many teachers allow pupils to take notes on the PC, but when I am lecturing they use pencil and paper, and that works better.

Another rule is to forbid the pupils to use SNS like Facebook or computer games $(n=3)$. Three of the teachers report that their pupils participated in making the rules. Some write that their school shares common rules $(n=6)$. Apparently a few classrooms have a zone without Internet $(n=3)$. The sanction may be to confiscate the pupil's computer for a period $(n=3)$.

Table 7 illustrates if the technology has influenced the way the classrooms are organized.

34 teachers have answered this question $(n=34)$. The most mentioned change is the need for more control. The classrooms are traditionally furnished with pupils' desks turned against the teachers'. Consequently when the computer is put on the desk teachers have to move from the front of the classroom to the back where they can see what is going on in the screens $(n=17)$. One teacher says:

I often go to the back of the classroom when my pupils use the computer. My strategies for 
TABLE 8: Extent of control.

\begin{tabular}{lc}
\hline \multicolumn{2}{c}{ To what extent do you feel that you control the pupils' use of } \\
technology in the classroom? \\
\hline To a very large extent & $9,2 \%$ \\
To a large extent & $29,2 \%$ \\
To some degree & $46,2 \%$ \\
To a small extent & $9,2 \%$ \\
To a very small extent & $4,6 \%$ \\
Not at all & $1,5 \%$ \\
\hline
\end{tabular}

TABLE 9: Training/education for teachers.

Do you find that you are offered enough training/courses concerning how to use ICT in the classroom?

\begin{tabular}{ll}
\hline Yes & $56,9 \%$ \\
No & $29,2 \%$ \\
Uncertain & $13,8 \%$ \\
\hline
\end{tabular}

coping with computers in teaching and learning are totally depending on the possibility of standing behind the pupils. Then I can see how they use the tool, how they work and when they slide away. It also tells me to see whom I should help.

From this group three teachers report that their school has a PC-free zone in the classroom with no Internet connection. Some teachers $(n=11)$ assert that the classroom is changed because of the practicalities computers require like, for example, sockets and projectors. Three mention that there are possibilities for learning in groups and in common, while two teachers are satisfied with the possibilities for variation and for keeping control and order. Finally one teacher says that using the Learning Management System (LMS) means that learning and guidance now takes place outside the walls of the classroom as well as inside.

Table 8 illustrates to what extent teachers feel that they control how pupils use the technology. The majority of teachers claim to have control on how the technology is used in the classroom.

Table 9 illustrates teachers' need for education concerning ICT in the classroom.

If no, what do you think you need more of? Altogether 29 respondents have answered the open questionnaire. The answers can be divided into three main categories. The first group is the one where the teachers want more information about how to use the technology. Activities like how to use, for example, PowerPoint, the Learning Management System (LMS), Smartboards, and iPads are mentioned $(n=9)$. One newly qualified teacher writes:

I would like to have a "crash-course" in how to use word, Exel, PowerPpoint, links to web-pages; that means all the technical details that everybody else seem to understand immediately. I must admit that I avoid some of these facilities because I feel silly and I do not want to reveal that I am not able to use it.
Another group are those teachers who learn how to use the technology on their own $(n=7)$. These teachers report spending a lot of their spare-time at home on learning how to use the technology for pedagogical purposes. Some are satisfied with this, others not. One teacher says that there should have been more possibilities for courses and training, while another teacher says:

I have not learned anything from courses or training in my school. All the education I have received is from my own initiative and my individual practice. I spend a lot of time at home in order to keep myself updated.

The third main group is the teachers who want more collective emphasis on the pedagogical use of technology in classrooms $(n=10)$. According to some of these teachers there has been enough emphasis on instruction in how to use the technology, but very little on how to use it for pedagogical purposes:

Far too often it means to put electricity on old learning activities. The main problem is that the technology is used as a substitute for the pencil or as a pedagogical tool for the same way of teaching and learning as earlier.

Another teacher says that he would like to communicate with and learn how other teachers and schools use the technology for pedagogical purposes. Initiatives from the authorities for pedagogical use of technological devices are asked for as in this case:

I miss the focus of how to use the technology for educational purposes in plans from schools and school administration. There is a great emphasis on pure competence in how to use the technology, but not on how to change practice in classrooms.

Summing up, the teachers who miss more training and education in use of ICT seem to have different needs. While one group wants more instruction in technical use, the other group has the opposite view and claims that too much emphasis has been put on instructional issues. What the latter group of teachers asks for is that authorities should put more emphasis on development of pedagogical use of technology and possibilities for collaborative development activities among teachers and schools.

The final question in the questionnaire asked the teachers the following question: Concerning the digital classroom what kind of challenges do you see? In all 55 persons answered this question $(n=55)$. Most concern is given to the challenge of continuing connection to Internet during school-days $(n=$ 48). The possibility for using social media is a constant threat to concentration and is concerning for teaching and learning according to the teachers $(n=26)$.

The problem is that pupils who need to concentrate are distracted. When pupils are using the PC it should be possible to differentiate and equalize. What happens is the opposite; 
differences are strengthened. With Internet open pupils spend a lot of time on activities that are not related to education like FB, web-pages for buying and selling cars and computer games, and so forth. If you do not stand right behind the pupil it is impossible to see what pages they are on and it is impossible to control how they use it. Pupils' excuses are that they have to take notes and it is difficult to deny them this activity.

Another group $(n=22)$ is concerned with the same problem viewed from the teacher as a leader's point of view. There seems to be a struggle going on between pupils and teachers about when to use the technology and not. Some teachers succeed in deciding when the pupils should use the Internet and not, while others give in.

The main challenge is to keep concentration on education not on the Internet. It is Utopian that we (the teachers) and the assignments should be able to compete for attention concerning all the entertainment that is possible to find on the Internet. Not many employers would have accepted that their employees spent many hours per day surfing the Internet and afterwards complain that they had too little time to do their duties. If we do not dare to discipline pupils' use of technology in schools the problems will escalate.

Possibilities and lack of such for closing down Internet is a matter of concern for many respondents. One teacher says that it should work the other way round; that teachers had to open Internet when they wanted their pupils to use it. Some respondents' concern is to know how to learn pupils criticism of sources and positive attitudes $(n=4)$ while others claim that they need more guidance in how to use digital media in education $(n=9)$. Practicalities like how to furnish the classroom is mentioned $(n=3)$ and one teacher complains that there is no more space on the desk when the computer is there.

To sum up the findings teachers would prefer to decide themselves when the pupils' computers should be connected to Internet or not. The main purpose for use of web-pages is to seek information and writing. The computers' interactive possibilities for student active learning methods are hardly mentioned. To a very little extent SNS is used for interactive purposes. To a large extent the teachers have established rules mainly to ensure that they as teachers and leaders should decide when to use the technology. Around 50\% claim that the introduction of technology has not influenced the way they furnish their classrooms, but teachers themselves have to move to the back to keep control. Concerning more knowledge of how to use the technology one group wants more instruction on how to use the technology, while another asks for more emphasis on how to use the technology for pedagogical purposes and for possibilities for development and collaboration between teachers and schools. The teachers' main concern for the future is the possibility for regulating when Internet should be used and not.

\section{Discussion}

The aim of the study was to gain more insight into how teachers experienced and practiced their role as leaders of the digital classroom. To address this aim the research questions focus on how the technology is used in the classrooms, and what the teachers' needs and expectations are concerning use of technology.

4.1. Traditional Classroom Pattern. This study, though limited in its generalization shows that the traditional pattern of classroom discourse [38] is the dominant. Pupils' desks are turned against the teachers' desks. What is new is the computer on each desk and the connection to Internet. For many teachers every lesson starts with a request of closing the computer screen. If they could decide they would prefer to be responsible for when the connection to Internet should be turned on or not. What should the computer be used for in classrooms where the dominant discourse pattern is IRE? The answers from this study seem to be to use websites as substitute for books and to collect information and to use it as a type-writer. To a very little extent the computers' interactive abilities seem to be utilized except for one teacher who mentions contact outside classrooms and approximately 15 percent who use SNS for educational purposes. When digital tests are carried out, the teacher moves to the other end of the classroom in order to reveal cheating. This means that the computer mainly is used for teaching and learning activities in line with the IRE pattern. Teachers ask pupils to use the computer for seeking information, for web-based assignments, and as a type-writer. This corresponds to other research within the field. Matusov et al. [47] claim that technology and particularly web-based facilities mainly are used for low-level tasks such as posting syllabus, distributing lecture notes, or administrating multiple-choice exams. The results also correspond to the Norwegian research report, Monitor 2016, claiming that Norwegian teachers mainly use technology for administrative purposes [6].

For teachers SNS is a great concern and problem for different reasons. First because pupils frequently visit these sites during lessons when they are supposed to listen and participate in the traditional teaching and learning activities, and second because they know that mobbing and harassing is taking place within the communities. The teachers are concerned with pupils' problems with concentration when they are supposed to listen to the teacher. Apparently teachers are in conflict between their own beliefs in teaching and learning activities and the challenges they are given when educational authorities want them to find out how to utilize online possibilities on pupils' computers for learning purposes. What seems to happen is that the teachers adjust use of technology to the teaching and learning activities they are used to and believe in $[29,30,41]$. Teachers use their agency [31] to follow their aims and beliefs and the way they use their agency may as well mean support to existing policies as restraint [32]. When the teachers in the current study were asked about their needs for more education concerning use of technology, their answers could be divided into three main categories. The first group and smallest group wanted 
more instruction on how to use the technology. The second group spent a lot of time at home trying to figure out how to use the technology purposefully, while the third group asked for more emphasis from authorities on pedagogical use of the technology and on possibilities for collaborative activities in order to develop new knowledge in the field. The results from the second and third group correspond to the results in the national research report Monitor 2013 [7] referring to teachers who said that their digital competence was most influenced through trial and failing and through collaboration with colleagues. Maybe we should listen to what the teachers say. Education is connected to the context. When teachers are going to use the technology they have to make decisions based on what works in their specific context. The easiest way out is to follow the same procedure as earlier: to continue with the IRE pattern and try to keep control. If new ways of using the technology more like student active learning activities Erstad [2] should be introduced teachers need to try and fail and discuss with colleagues.

What this study shows is that in order to change practice it is not enough to put technology into the classroom. Teachers did not ask for it [18]. What happens is that teachers adjust the use of the technology to their existing practice. According to Callister and Dunne [21] inventions come and go and practice is the same. However, as researchers have pointed out, the new technology is more powerful than other equipment teachers have been offered or imposed $[10,24]$. Teachers in this study want to decide when to use the Internet or not. They miss the opportunity of choosing when pupils should be online or not. What may be a threat when teachers have lost the possibility of this decision is that they become suspicious and need to have even more control, taking education out of the hands of educators and into the hands of administrators [45].

4.2. Future Concerns. According to Castells [17] education is the social activity that is most challenged by the network society. Internet has defied our notion of what counts as knowledge. There is a gap between policymakers' ambitions in the field of educational technology and the results from surveys that reveal that teachers mainly use technology for administrative and not for pedagogical purposes [6, 7]. Information and communication technologies do not themselves determine innovation. There might be many possible reasons for the discrepancy between the political request and reality inside schools and classrooms. One possible reason is that the initiative to the investment in educational technology does not come from schools and teachers themselves. While political documents recognize the computer as an instrument for learning, many teachers are sceptic. The decisions are made from the top-down without possibilities for teachers to participate. If computers are placed inside a classroom this seems to be perceived as a guarantee for learning to take place [19]. Teachers are not consulted even if they are the actors that are supposed to use the computers in their education. The initiatives and premises for introduction of technology in classrooms have been decided outside schools' and teachers' decision-making. There seems to be a gap between political aims and reality, reinforced with a strong belief in the fact that if educational technology is introduced as part of the learning environment learning is going to occur $[10,19,48]$. This problem is not exceptional to the Norwegian context. Around the world, when visionary policy initiatives result in minimal change in classroom practice evaluators tend to blame teachers and urge more training for them [49]. Teachers' resistance is looked upon as the main obstacle against development. What these evaluators tend to overlook is the relationship between teachers' beliefs concerning pedagogical reasoning.

When it comes to practice in classrooms teachers use their agency and decide how to use the technology [31]. According to Toom et al. [50] and Beijaard and Van der Heijden [51] acknowledging teachers' agency seems to be important for pupils' learning and for understanding teachers' professional development and school development.

\section{Disclosure}

The study has previously been presented at the ECER conference [52].

\section{Conflicts of Interest}

The authors declare that they have no conflicts of interest.

\section{Acknowledgments}

The authors want to thank the University of Bergen, Norway, for the funding of the publication of this article.

\section{References}

[1] M. Blikstad-Balas, "Digital literacy in upper secondary schoolwhat do students use their laptops for during teacher instruction?" Nordic Journal of Digital Literacy, vol. 7, no. 2, pp. 81-96, 2012.

[2] O. Erstad, Digital kompetanse i skolen- en innføring. [Digital Competence in school-an introduction], Universitetsforlaget, Oslo, Norway, 2010.

[3] Ministry of Education and Research (MER), [Undervisningsog forskningsdepartementet] [UFD]. The Program for digital competence 2004-2008 [Program for digital kompetanse 20042008; in Norwegian], Norwegian, 2003, https://www.regjeringen .no/globalassets/upload/kd/vedlegg/grunnskole/strategiplaner/ program_for_digital_kompetanse_liten.pdf.

[4] Ministry of Education and Research (MER), The Knowledge Promotion. The New National Curriculum, 2006, https://www .regjeringen.no/globalassets/upload/kilde/kd/bro/2006/0002/ ddd/pdfv/292311-kunnskapsloftet2006_engelsk_ii.pdf.

[5] Ministry of Education and Research (MER) (2008-2009). Whitepaper 11, [Undervisnings- og forskningsdepartementet] [UFD]. The Teacher. Role and Education. [Læreren Rollen og utdanningen; in Norwegian] Retrieved March 03, 2017, from: http://www.regjeringen.no/nb/dep/kd/dok/regpubl/stmeld/20082009/stmeld-nr-11-2008-2009-.html?id=544920.

[6] G. Egeberg, H. Hultin, and O. Berge, "Skolens digitale tilstand. Monitor skole. IKT-senteret," https://iktsenteret.no/ressurser/ monitor-skole-2016.

[7] O. E. Hatlevik, G. Egeberg, G. B. Gudmundsdottir, M. Loftsgarden, and M. Loi, Om digital kompetanse og erfaringer 
med bruk av IKT i skolen. Monitor (2013). IKT-senteret. Oslo. https://iktsenteret.no/ressurser/monitor-skole-2013\#.VRZQIqPKzIU.

[8] W. Sugar, F. Crawley, and B. Fine, "Examining teachers' decisions to adopt new technology," Educational Technology and Society, vol. 7, no. 4, pp. 201-213, 2004.

[9] S. Kurt, "How do teachers prioritize the adoption of technology in the classroom?" Teachers and Teaching: Theory and Practice, vol. 18, no. 2, pp. 217-231, 2012.

[10] J. Underwood and G. Dillon, "Chasing dreams and recognising realities: Teachers' responses to ICT," Technology, Pedagogy and Education, vol. 20, no. 3, pp. 317-330, 2011.

[11] N. Bakir, "An exploration of contemporary realities of technology and teacher education: lessons learned," Journal of Digital Learning in Teacher Education, vol. 31, no. 3, pp. 117-130, 2015.

[12] H.-J. So, H. Choi, W. Y. Lim, and Y. Xiong, "Little experience with ICT: are they really the Net Generation student-teachers?" Computers and Education, vol. 59, no. 4, pp. 1234-1245, 2012.

[13] R. Scherer, F. Siddiq, and T. Teo, "Becoming more specific: measuring and modeling teachers' perceived usefulness of ICT in the context of teaching and learning," Computers and Education, vol. 88, pp. 202-214, 2015.

[14] M. Orvik, Nettbrettvett: En studie av utprøving av nettbrett i grunnskolen, med vekt på lærerens digitale kompetanse. Tablets in Primary School. A study of teachers' digital Competence, 2012 Masteroppgave: Universitetet i Oslo. Retrieved February 02, 2017 from: https://www.duo.uio.no/bitstream/handle/10852/ 34346/Masteroppgave_Orvik.pdf?sequence=1\&amp;isAllowed=y.

[15] D. Bebell, M. Russell, and L. O’Dwyer, "Measuring teachers technology uses: Why multiple-measures are more revealing," Journal of Research on Technology in Education, vol. 37, no. 1, pp. 45-63, 2004.

[16] C. Taylor, The Malaise of Modernity, Stoddart Publishing Co. Ltd, Canada, 1991.

[17] M. Castells, The internet galaxy: Reflections on the internet, business and society, Oxford University Press, New York, NY, USA, 2002.

[18] P. Rodríguez, M. Nussbaum, and L. Dombrovskaia, "ICT for education: A conceptual framework for the sustainable adoption of technology-enhanced learning environments in schools," Technology, Pedagogy and Education, vol. 21, no. 3, pp. 291-315, 2012.

[19] L. Cuban, Teachers And Machines: The Classroom Use of Technology since, Teachers College Press, Columbia University, New York, NY, USA, 1986.

[20] C. Castro, "Are new technologies better technologies? for whom?" in Adapting technology for school improvement: A global perspective, D. W. Chapman L and L. O. Mählck, Eds., pp. 39-54, International Institute for Educational Planning, UNESCO.

[21] T. Callister and F. Dunne, "The computer as doorstep: Technology as disempowerment," Phi Delta Kappan, vol. 74, no. 4, pp. 324-326, 1992.

[22] L. Cuban and D. Tyack, Tinkering Toward Utopia, Harvard University Press, Cambridge, UK, 1998.

[23] S. Papert, Tankestormar, alternativ pedagogic med datorns hjälp. [Mindstorms, Children, Computers and Powerful ideas; in Swedish], Forum, Stockholm, 1984.

[24] R. Säljö, Lärande i praktiken; et sociokulturelt perspektiv. [Learning in Practice in a socio-cultural perspective; in Swedish], Prisma, Stockholm, 2000.
[25] A. McFarlane, "Perspectives on the relationships between ICT and assessment," Journal of Computer Assisted Learning, vol. 17, no. 3, pp. 227-234, 2001.

[26] G. Sunkel, . Las Tecnologías de La Información y la Comunicación (Tic) en la educación en América Latina. Una exploración de indicadores [ICT in Latin America: exploring indicators]. CEPAL - Politicas sociales (Division de Desarrollo Social, CEPAL, Naciones Unidas). United Nations, 2006.

[27] M. Trucano, "Knowledge maps: ICTs in education," in ICT and Education Series, infoDev/World Bank, Washington, DC, USA, 2005.

[28] A. Balanskat, R. Blamire, and S. Kefalla, The ICT impact report: a review of studies of ICT impact on schools in Europe, European Schoolnet, 2006.

[29] B. Somekh, J. Underwood, A. Convery et al., Evaluation of the ICT Test Bed Project, Nottingham Trent University, Nottingham, UK, 2006.

[30] M. F. Pajares, "Teachers' beliefs and educational research: cleaning up a messy construct," Review of Educational Research, vol. 62, no. 3, pp. 307-332, 1992.

[31] H. W. Oolbekkink-Marchand, L. Hadar, K. Smith, I. Helleve, and M. Ulvik, "Teachers perceived professional space and their agency," Teaching and Teacher Education, vol. 62, pp. 37-46, 2017.

[32] M. Priestley, G. Biesta, S. Phillippou, and S. Robinson, The SAGE Handbook of Curriculum Pedagogy and Assessment, SAGE, London, UK, 2015.

[33] I. Helleve, "The networked classroom-socially unconnected," Education Inquiry, vol. 4, no. 2, pp. 395-412, 2013.

[34] J. Sinclair and R. Coulthard, Towards an analysis of discourse. The English used by teachers and pupils, Oxford University Press, London, UK, 1975.

[35] H. Mehan, Learning lessons. The social organization of classroom instruction, Harvard University Press, Cambridge, UK, 1979.

[36] C. Cazden, Classroom discourse. The language of teaching and learning, Heinemann, Portspouth, UK, 1998.

[37] A. D. Edwards and N. Mercer, Common knowledge. The development and understanding of the classroom, Methuan, London, UK, 1987.

[38] J. Wertsch, Mind as action, Oxford University Press, New York, NY, USA, 1998.

[39] V. G. Johnson, "Student Teachers' Conceptions of Classroom Control," Journal of Educational Research, vol. 88, no. 2, pp. 109117, 1994.

[40] H. Kurt, "An Evaluation of Teachers' Attitudes and Beliefs Levels on Classroom Control in Terms of Teachers' Sense of Efficacy," Education, vol. 134, no. 3, pp. 285-297, 2014.

[41] I. Helleve, "Den komplekse l $\mu$ rerrolla [The complex role as a teacher]," in Den digitale lurergenerasjonen, utfordringer og muligheter [The digital role of the teacher, possibilities and challenges], I. Helleve, A. Almås, and B. Bjørkelo, Eds., pp. 1930, Gyldendal Akademisk, Oslo, Norway, 2016.

[42] N. Mercer and E. Fisher, "Scaffolding through talk," in Computers and Talk in Primary Classrooms, R. Wegerif and P. Schrimshaw, Eds., pp. 196-210, Multilingual Matters, Clevedon, UK, 1997.

[43] R. Wegerif, Dialogic Education and Technology, Springer, Lausanne, Switzerland, 2007.

[44] J. L. Lebrun, Scientific Writing, World Scientific Publishing Company, 2007. 
[45] M. Kompf, "Information and communication technology (ICT) and the seduction of knowledge, teaching, and learning: what lies ahead for education," Curriculum Inquiry, vol. 35, no. 2, pp. 213-233, 2005.

[46] I. Helleve and C. Johnsen, Skulen sine dilemma i den digitale kvardagen. The school's dilemmas in the digital weekday, Utdanning, 6, 52-55, 2012.

[47] E. Matusov, R. Hayes, and M. J. Pluta, "Using discussion webs to Develop an academic community of learners," Educational Technology and Society, vol. 8, pp. 16-39, 2005.

[48] V. Kløvstad, O. Erstad, T. Krisitansen, and M. Søby, ITU Monitor 2005. På vei mot en digital kompetanse i grunnopplæringen. ITU Monitor 2005. Towards a digital competence in primary education; in Norwegian, Rapport 2/2005. Oslo, Universitetsforlaget.

[49] B. Somekh, "Factors affecting teachers pedagogical adoption of ICT," in International Handbook of Information Technology in Primary and Secondary Education, J. Voogt and G. Knezek, Eds., pp. 449-460, Springer Science, Business Media, Berlin, Germany.

[50] A. Toom, K. Pyhältö, and F. O. Rust, "Teachers professional agency in contradictory times," Teachers and Teaching: Theory and Practice, vol. 21, no. 6, pp. 615-623, 2015.

[51] G. D. Beijaard and G. Van der Heijden, "Characteristics of teachers as change agents," Teachers and Teaching: Theory and Practice, vol. 21, no. 6, pp. 681-699, 2015.

[52] I. Helleve and A. G. Almås, "Teachers in the Digitized Classroom," in Proceedings of the European Conference on Educational Research, 2016, http://www.eera-ecer.de/ecer-programmes/conference/21/contribution/37019/. 


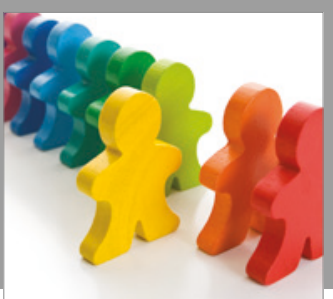

Autism

Research and Treatment
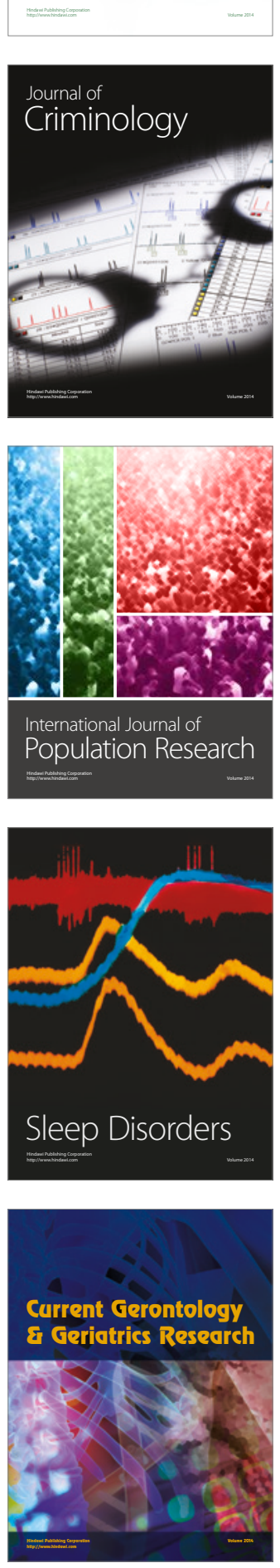

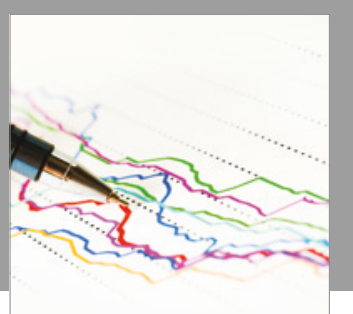

Economics

Research International

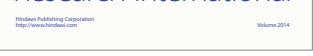

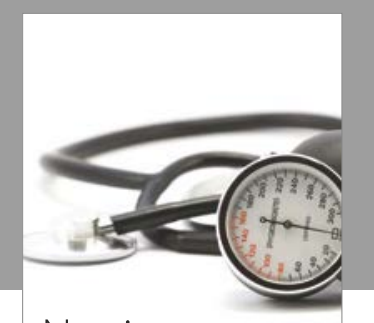

Nursing

Research and Practice

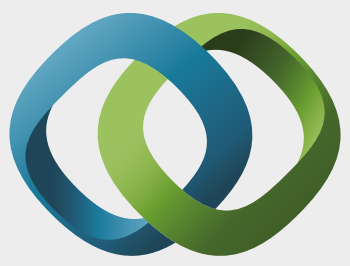

\section{Hindawi}

Submit your manuscripts at

https://www.hindawi.com
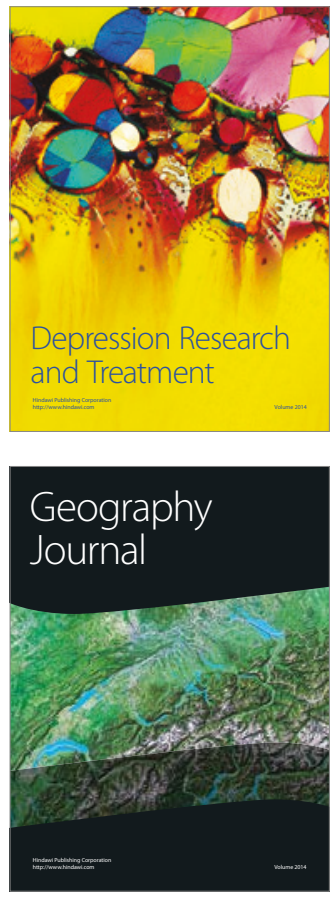
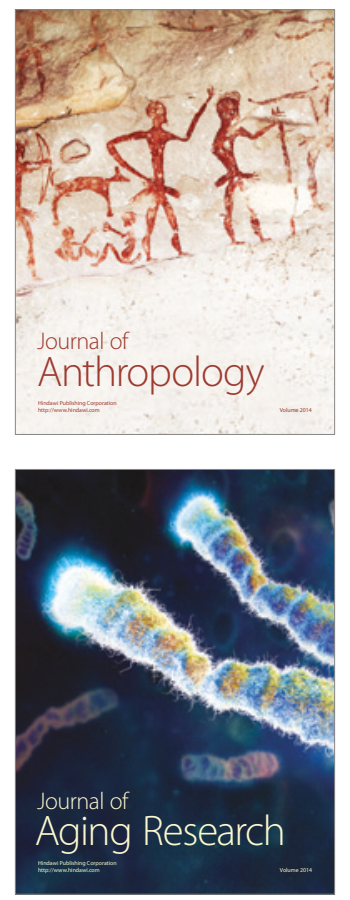
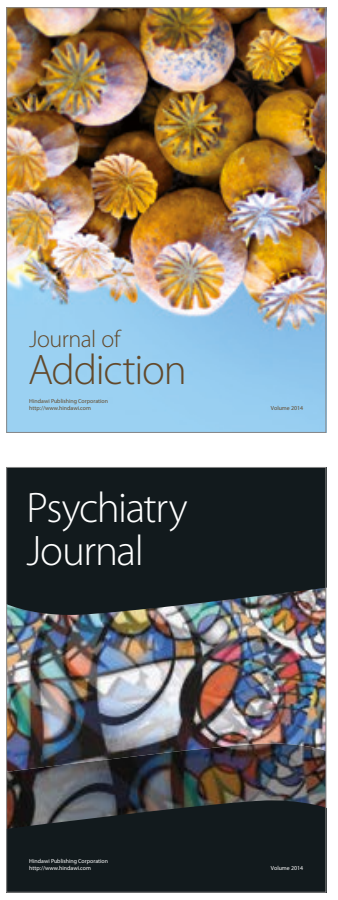

Child Development

Research

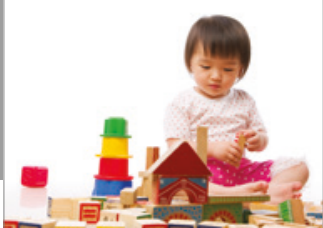

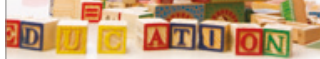
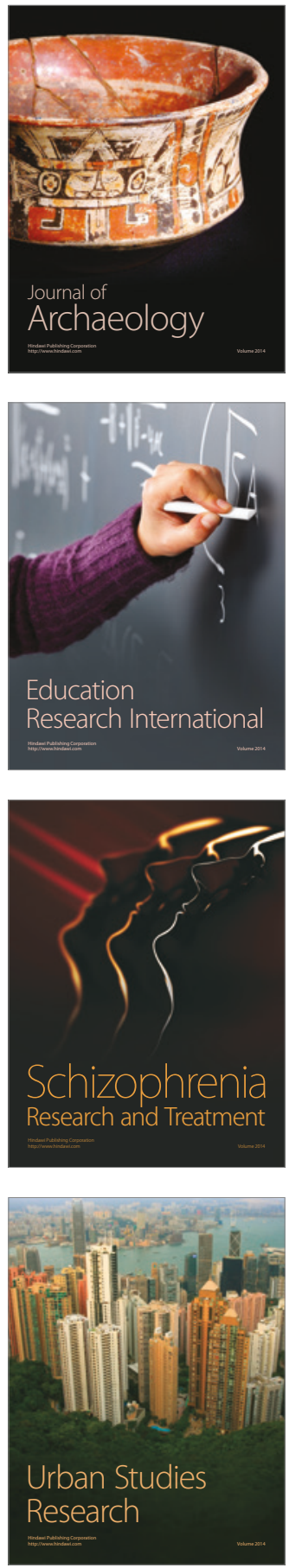